Portland State University

PDXScholar

2016

\title{
Attitudes Among Legal Professionals: Measuring for a Difference in Attitudes Towards Science
}

Jonathen N. Gates

Portland State University

Follow this and additional works at: https://pdxscholar.library.pdx.edu/honorstheses

Let us know how access to this document benefits you.

\section{Recommended Citation}

Gates, Jonathen N., "Attitudes Among Legal Professionals: Measuring for a Difference in Attitudes Towards Science" (2016). University Honors Theses. Paper 322.

https://doi.org/10.15760/honors.291

This Thesis is brought to you for free and open access. It has been accepted for inclusion in University Honors Theses by an authorized administrator of PDXScholar. Please contact us if we can make this document more accessible: pdxscholar@pdx.edu. 
Attitudes Among Legal Professionals: Measuring for a Difference in Attitudes Towards Science

$$
\text { by }
$$

Jonathen N. Gates

An undergraduate honors thesis submitted in partial fulfillment of the

\author{
requirements for the degree of \\ Bachelor of Science \\ in \\ University Honors \\ and \\ Political Science
}

Thesis Adviser

Lindsay Benstead

Portland State University 


\section{Introduction}

Litigation within the U.S. common law system relies on codes and statutes which are constructed by legislatures and interpreted by the courts. There need not be any reason, besides political gain, for a legislator to author a statute. And opinions of the courts are based on interpretations of earlier interpretations of widely varied, some might argue irrelevant, precedent. In essence, there is a significant arbitrary quality to the law. Conversely, one may observe that the only law in science is that nothing is ever truly proven. No evidence is protected by a $4^{\text {th }}$ amendment to the scientific method. It should not be surprising then, that the intersection of these fields can ignite tension in both. Nor that state of mutual distrust appears to exist, having begun nearly as soon as scientific expert testimony entered practice within the legal system. ${ }^{1}$ Does such distrust, perhaps resulting from a divergence of professional values or from negative experience when working with experts, affect the attitudes of legal professionals towards science? Because of their prevalence in critical and influential roles, working as members of Congress, members of the bureaucracy, lobbyists, and organizational directors, ${ }^{2}$ the purpose of this research project was to determine whether there is evidence that legal professionals hold more negative views of the scientific community than their peers in other professions. The results of this analysis suggest that they may, in fact, hold higher esteem for the scientific community than many of their peers, however, available data is not sufficient to make a statistically significant determination.

For background this paper will work first to conduct a literature review which examines the myriad difficulties surrounding the use of scientific expert testimony, which is where the

\footnotetext{
${ }^{1}$ Haack, Susan. "Irreconcilable Differences? The Troubled Marriage of Science and Law." Law \& Contemporary Problems 72, no. 1 (Winter 2009): p. 2

2 Southworth, Ann, Anthony Paik, and John P. Heinz. "Lawyers in National Policymaking." SSRN Scholarly Paper. Rochester, NY: Social Science Research Network, May 10, 2010. http://papers.ssrn.com/abstract=1604080.
} 
basic argument for an expected difference in attitudes finds its basis. To provide context the review will outline a doctrinal argument which blames current and past judicial rule-making for the conflict. If confidence is impacted by the action of such judicial rule-making, one should expect to find any variance that is limited to persons regularly involved with scientific expert testimony. A review of a theory concerning a divergence of values and practices will follow. If such a divergence impacts confidence, one should expect to find a more general variance among all legal professionals. The theoretical basis of the research question will be explicated within these reviews. Second an outline of the research data for this project will include: the theoretical approach, methodology, variables and measures, and regression results. Third a discussion of the results including what the data suggests as a next step will be conducted. Finally, conclusions will be presented which include considerations provided for possible future research.

\section{Background}

Television, film, and print media present an image of the intersection of science and the law that is not generous to either field. Viewers and readers are shown expert witnesses dispensing "junk science" 3 to further the interests of powerful attorneys and their clients, be they plaintiff or defendant. ${ }^{4}$ Is there some factual basis which accounts for this representation? Consider the tobacco industry for a moment. Beginning in the 1950s there was a series of cases that attempted to hold cigarette manufactures liable for cancer which was afflicted upon smokers. ${ }^{5}$ The litigation of those cases included many instances of scientific testimony. Those testimonies, in hindsight, included some of the most influential junk science that tobacco money could buy. ${ }^{6}$ Experts were employed by the tobacco industry to convince judges and juries that regardless of

\footnotetext{
${ }^{3}$ Huber, Peter W. Galileo's Revenge: Junk Science in the Courtroom. Basic Books, 1993.

${ }^{4}$ See Coppola, Francis Ford. The Rainmaker. Crime, Drama, Thriller, 1997.

${ }^{5}$ Freedman, Alix M., and Laurie P. Cohen. Wall Street Journal, Eastern Edition. February 11, 1993.

6 Ibid.
} 
what other data suggested, their data proved that there was no link between tobacco and cancer or other illness. ${ }^{7}$ These efforts were successful for many years. Today we can see that the data upon which these claims were based was not representative, but instead used outlier examples, picked from the fringe, ${ }^{8}$ accompanied by very certain rhetoric to defend an interest. So it appears there is some factual basis for the unflattering representation media makes of the intersection of science and law.

Conservative author Peter Huber ${ }^{9}$ is considered by some to be an expert regarding science and the law. ${ }^{10}$ He has blamed junk science, proffered by profit-minded attorneys, for significant harm to American companies and the consumers who purchase from them. ${ }^{11}$ Huber makes an example of the discontinuation of the drug Bendectin, which was used to treat nausea in pregnant women. While this drug was never declared unsafe by regulators, it was removed from shelves by Merrell Dow Pharmaceuticals following a series of lawsuits which attempted, in opposition to the medical consensus, to associate the drug with the occurrence of birth defects. ${ }^{12}$ The cost of continuing to litigate ultimately exceeded the value of the drug to the company. ${ }^{13}$ Consequently, one estimate suggests that disuse of Bendectin created approximately $\$ 73$ million in additional medical expenses in the U.S. alone, related to nausea in pregnant women, over one decade. ${ }^{14}$ Overall Huber argues that examples like this, or like a woman awarded $\$ 1$ million for

\footnotetext{
7 Ibid.

${ }^{8}$ Ibid.

${ }^{9}$ Peter W. Huber is a partner at the law firm of Kellogg, Huber, Hansen, Todd, Evans \& Figel, and an author and senior fellow at the Manhattan Institute.

${ }^{10}$ Huber has been cited by both the U.S. Supreme Court in BFI, Inc. v. Kelco Disposal, Inc. 492 U.S. 257 (1989) and by the U.S. Court of Appeals for the Ninth Circuit in Daubert v. Merrell Dow Pharmaceuticals, Inc. 43 F.3d 1311 (1995) on remand.

${ }^{11}$ Huber, Galileo's Revenge, p.190.

12 Huber, Galileo's Revenge, p.113.

${ }^{13}$ Peter W. Huber, Liability: The Legal Revolution and Its Consequences (New York: Basic Books, 1990) p.102.

${ }^{14}$ R. Brent, "Medical, Social, and Legal Implications of Treating Nausea and Vomiting of Pregnancy," American Journal of Obstetrics \& Gynecology 186, no. 5 (May 18, 2002): 262-66.
} 
the loss of her psychic powers ${ }^{15}$ demonstrate the willingness of legal professionals to seek out the least competent, or perhaps most pliable, members of the scientific community to substantiate their liability claims. Although he discusses the availability of researchers who are willing to declare themselves modern Galileos, lone geniuses regardless of current consensus, Huber places the blame firmly within the legal system. He and Kenneth Foster ${ }^{16}$ opine

Junk science arises when a witness seeks to present grossly fallacious interpretations of scientific data or opinions that are not supported by scientific evidence. Junk science is a legal problem, not a scientific one. It is cultivated by the adversarial nature of legal proceedings, and it depends on the difficulty many laypeople have in evaluating technical arguments. ${ }^{17}$

His argument works to provides implicit support for a concern that experience in practice creates an environment which may damage legal professionals' confidence in science.

A weakness with Huber's assertions though, lies in his characterization of companies and corporations as the primary victims of junk science in the courtroom. Earlier work by Marc Galanter ${ }^{18}$ provides a model to examine the limits of legal change which demonstrates why Huber's focus works against his argument for a doctrinal resolution. Galanter develops a typology of parties who participate in litigation which includes Repeat Players (RP) and OneShotters (OS). He describes “... the RP is a larger unit and the stakes of any given case are smaller (relative to total worth). OSs are usually smaller units and the stakes ... may be high relative to total worth, as in the case of injury victim or the criminal accused."19 Large companies,

\footnotetext{
${ }^{15}$ Huber, Galileo's Revenge, p.4.

${ }^{16}$ Kenneth R. Foster is a Professor of Bioengineering at the University of Pennsylvania and contributor to the discussion of science as used by law.

17 1. Kenneth R. Foster and Peter W. Huber, Judging Science: Scientific Knowledge and the Federal Courts (MIT Press, 1999) p.17.

${ }^{18}$ Marc Galanter is a Professor of Law and South Asian Studies at the University of Wisconsin - Madison and LSE Centennial Professor at the London School of Economics and Political Science.

${ }^{19}$ Galanter, Law and Society Review, p. 98
} 
interest groups, and governments will nearly universally function as RPs, although Galanter stresses there is a continuum between these groups. ${ }^{20}$ He further presents a list of factors which tend to favor RPs including: advance intelligence from prior litigation; expertise in their field and access to specialists without necessary additional cost; access to economies of scale in instances where additional cost is necessary; access to facilitative informal relations with members of judicial or other institutions; credibility from prior litigation; resources with which to play the odds; freedom to play for immediate gain or long term rules change. ${ }^{21}$ RP organizations are thus able to strategically settle cases likely to end poorly in a trial. While RPs may be the most prevalent targets for litigation, which is itself an unsubstantiated claim, ${ }^{22}$ they are also those most capable of gaining rule changes in their favor. Whether or not the practice affects legal professionals' attitudes, Galanter's work suggests that it may be self-inflicted, and not simply a matter of doctrinal failure.

Contemporaneous to the publication of Huber's book Galileo's Revenge the American judicial system underwent significant change regarding expert witness testimony. Federal courts are today bound to operate within the guidelines provided by Federal Rules of Evidence (FRE). Many state courts have also accepted similar or modified versions of the current federal standards including those for expert witness testimony; FRE 702. This rule, which has been in force in some form since 1975, today reads:

Rule 702. Testimony by Expert Witnesses

A witness who is qualified as an expert by knowledge, skill, experience, training, or education may testify in the form of an opinion or otherwise if:

(a) the expert's scientific, technical, or other specialized knowledge will help the trier of fact to understand the evidence or to determine a fact in issue;

\footnotetext{
${ }^{20}$ Galanter, Law and Society Review, p. 98-99

${ }^{21}$ Ibid.

${ }^{22}$ Kenneth J. Chesebro, “Galileo’s Retort: Peter Huber’s Junk Scholarship,” American University Law Review 42, no. 4 (1993): 1637-1726.
} 
(b) the testimony is based on sufficient facts or data;

(c) the testimony is the product of reliable principles and methods; and

(d) the expert has reliably applied the principles and methods to the facts of the case. $^{23}$

Until 1993 prior case law drawn from Frye v. United States (293 F. 1013 ( D.C.. Cir 1923)), established a requirement for general acceptance of a theory or method within the relevant field of study before testimony based in such theory or method could be admitted as evidence. ${ }^{24}$ In 1993 however, the Supreme Court decided in a series of cases beginning with Daubert v. Merrell Dow Pharmaceuticals (509 U.S. 579 (1993)) that FRE 702 implicitly overturned Frye. This case and two following ${ }^{25}$ cases created a new standard of testing admissibility which operates in tandem with FRE 702, the Daubert standard requires consideration of:

(1) whether the theory or technique in question can be and has been tested; (2) whether it has been subjected to peer review and publication; (3) its known or potential error rate; (4) the existence and maintenance of standards controlling its operation; and (5) whether it has attracted widespread acceptance within a relevant scientific community.

These decisions tasked federal judges with significant new gatekeeping responsibilities related to expert testimony.

A question arising from the adoption federally, and in many states, of the Daubert standard is whether such doctrinal or procedural change influences the inclusion or acceptance of expert testimony. Has the rule change made it more difficult, as Huber believes, to influence the legal process with junk science? Research by Cheng ${ }^{26}$ and Yoon $^{27}$ in 2005 suggests that it has

\footnotetext{
${ }^{23}$ Federal Rules of Evidence Article VII. Opinion and Expert Testimony-Rule 702. Testimony by Expert Witnesses

${ }^{24}$ This is generally referred to as the Frye standard.

${ }^{25}$ See General Electric Co. v Joiner, 522 U.S. 136 (1997) and Kumho Tire Co., Ltd. v Carmichael, 526 U.S. 137 (1999)

${ }^{26}$ Edward K. Cheng is an Assistant Professor of Law, Brooklyn Law School; J.D., Harvard Law School; M.Sc., London School of Economics; B.S.E., Princeton University.
} 
not. ${ }^{28}$ Examining state courts, which house the vast majority of $\operatorname{tort}^{29}$ litigation, ${ }^{30}$ their study calculated the rate of removal to federal courts. No statically significant variance was found between the Eastern District of New York (EDNY) or Connecticut, which rely on Frye and Daubert respectively. ${ }^{31}$ The authors argue that significant variance should be seen if the Daubert standard, a controlling rule in federal courts, provides better rates of exclusion for expert or science testimony. ${ }^{32}$ If Daubert were working to improve the exclusion of junk science, or the rate of admitting qualified science, we would expect to see statistically significant percentage variance in rate of removal between Frye and Daubert jurisdictions as applicable defendants move to take advantage of the doctrine. The implicit conclusion which can be drawn here is that even with substantial doctrine change the environment has not changed significantly, any factors that have motivated mistrust between scientists and legal professionals likely remain. A 2002 research report of the Federal Judicial Center ${ }^{33}$ provides additional support both for Cheng and Yoon's research and the continuing presence of an acidic relationship between the fields of science and law. ${ }^{34}$

Doctrine however, may not be the only issue, it is possible that there is a more fundamental difference responsible for the relationship of distrust between the fields. In fact, the historical presence of distrust discussed earlier is offered by a source who argues that point

\footnotetext{
${ }^{27}$ Albert H. Yoon is an Associate Professor of Law, Northwestern University School of Law; Visiting Professor, NYU School of Law (Fall 2004); Ph.D., Stanford University (Political Sci- ence); J.D., Stanford Law School; B.A., Yale University.

${ }^{28}$ Edward K. Cheng and Albert H. Yoon, "Does Frye or Daubert Matter? A Study of Scientific Admissibility Standards," Virginia Law Review 91, no. 2 (2005): 471-513.

${ }^{29}$ A tort is conduct that causes harm and amounts to a legal wrong for which courts impose civil liability. Wex Legal Dictionary

${ }^{30}$ Cheng and Yoon, Virginia Law Review, p. 473.

${ }^{31}$ Cheng and Yoon, Virginia Law Review, p. 489.

${ }^{32}$ Cheng and Yoon, Virginia Law Review, p. 483.

${ }^{33}$ The Federal Judicial Center is the education and research agency for the U.S. federal courts.

${ }^{34}$ Krafka et al., "Judge and Attorney Experiences, Practices, and Concerns Regarding Expert Testimony in Federal Civil Trials."
} 
exactly. Susan Haack ${ }^{35}$ and Joseph Sanders ${ }^{36}$ both present descriptions of a proposed difference at the most basic levels. Haack begins by noting that complaints have abounded about the use of science by lawyers, ${ }^{37}$ as is easily observed from even cursory research. Complaints have centered on perceived dishonesty of scientific witnesses and on a perceived scientific ignorance of non-expert participants. ${ }^{38}$ Haack's perspective suggests that these are to be expected. Her central argument is that “... there are deep tensions between the goals and values of the scientific enterprise and the culture of law, especially the culture of the U.S. legal system." ${ }^{39}$ Sanders echoes this assessment and offers an enumeration of their summarized conventions of science:

Scientific conventions involve: (1) searching for the general and theoretical, (2) employing the methods and techniques accepted by one's field, (3) an attitude of agnosticism that encourages waiting for persuasive evidence before making up one's mind, and (4) a commitment to sharing data, intellectual honesty, and disinterestedness. ${ }^{40}$

Even without a legal education, one can easily see where conflicts are likely to arise. For instance, as Sanders explains, while scientific conventions focus on the generalizable, legal inquiry focuses on experience and specific events. ${ }^{41}$ Legal procedures are also necessarily limited in time, they cannot await persuasive evidence that is not available on demand. Witnesses are pushed to make a decision with a reasonable degree of certainty in a timely fashion.

Another clear distinction between the conventions of the American legal system and institutional science is related to the relative importance of factual truth and intellectual honesty.

\footnotetext{
${ }^{35}$ Susan Haack is a Professor in the Humanities, Cooper Senior Scholar in Arts and Sciences, Professor of Philosophy, and Professor of Law at the University of Miami.

${ }^{36}$ Joseph Sanders is a Professor of Law at the University of Houston Law Center.

${ }^{37}$ Susan Haack, "Irreconcilable Differences? The Troubled Marriage of Science and Law," Law \& Contemporary Problems 72, no. 1 (Winter 2009): 1-23.

${ }^{38}$ Haack, Law \& Contemporary Problems, p. 2

${ }^{39}$ Ibid.

${ }^{40}$ Sanders, Joseph. "SCIENCE, LAW, AND THE EXPERT WITNESS.” Law and Contemporary Problems 72 , no. 1 (January 1, 2009): 63-90. p. 66

${ }^{41}$ Sanders, Law and Contemporary Problems, p. 67
} 
Monroe Freedman ${ }^{42}$ and Abbe Smith $^{43}$ are important sources regarding this point. In their book Understanding Lawyers' Ethics they discuss “the ethical standards that are held by a large portion of the practicing bar." 44 While their arguments are sound from the ethical perspective of a client-focused advocate, the proposed response to known truthful testimony is clearly at odds with the values of science. They state definitively; "Is it ever proper for a lawyer to crossexamine an adverse witness who has testified accurately and truthfully in order to make the witness appear to be mistaken or lying? Our answer is yes - but the same answer is also given by almost every other commentator on lawyer's ethics."45

Haack relates how the valuation of factual truth is lessened in other ways within the legal system. She relates Justice Blackmun's statements about the stark difference between scientific and legal methods for determining the truth and the epistemic value of those determinations. For American law, the process is adversarial, effectively leaving only two possible truths to be decided between. Perhaps most importantly it is "subject to the relevant standard of truth, under the constraint of rules, some of which mandate the exclusion of relevant evidence for reasons that are not even obliquely truth-related." ${ }^{46}$ Although institutional science is of course limited for ethical reasons in areas such as living subject experimentation, there are not any systemic rules which preclude the use of any particular evidence. In fact, what rules do exist, in academic or other environments, will generally be directed at preventing attempts to gain evidence unethically, not on suppressing information that has already been found.

\footnotetext{
${ }^{42}$ Monroe H. Freedman was a Professor of Law and the former Dean at Hofstra Law School, lecturer at Harvard Law School, and a visiting professor at Georgetown Law School.

${ }^{43}$ Abbe L. Smith is a criminal defense attorney and professor of law at Georgetown University Law Center, Director of the Criminal Defense and Prisoner Advocacy Clinic, and Co-Director of the E. Barrett Prettyman Fellowship Program.

${ }^{44}$ Smith, Abbe, and Monroe H Freedman. Understanding Lawyers' Ethics. New Providence, NJ: LexisNexis, 2010. p. vii

${ }^{45}$ Smith and Freedman, Understanding Lawyers' Ethics, p. 213

${ }^{46}$ Haack, Law \& Contemporary Problems, p. 13
} 
Haack and Sanders are not alone in their assertions; other academics within the legal community have also developed an understanding of the constraints which exist between science and law. David L. Faigman, ${ }^{47}$ John Monahan, ${ }^{48}$ and Christopher Slobogin ${ }^{49}$ argue that

Fundamental differences exist between how scientists describe phenomena as scientists and how trial courts expect scientists to describe those phenomena. Scientists, in their professional lives, almost invariably measure phenomena at the group level and describe their results statistically. Trial courts, in contrast, typically consider cases individually and call upon scientific experts to describe their results categorically. ${ }^{50}$

The observations of Haack, Sanders, Faigman, Monahan, and Slobogin provide clear examinations of the factors, in addition to experience from practice, that may fuel as state of distrust between science and law. There is significant reason to expect that such fundamental differences may impact legal professionals' attitudes. Thus there is also reason to expect that legal professionals will have less confidence in the scientific community than their peers in other fields

\section{Research Data}

\section{Theoretical approach}

This research attempts to identify whether legal professional's attitudes towards science, expressed as confidence in the scientific community, are less than those of persons in other fields. The question is based in an analysis of the environment that exists related to scientific testimony and legal procedure. There is reason to suspect a variation between legal and other professionals

\footnotetext{
${ }^{47}$ David L. Faigman is Acting Chancellor \& Dean of the University of California Hastings Law School.

${ }^{48}$ John Monahan is the John S. Shannon Professor of Law at the University of Virginia Law School.

${ }^{49}$ Christopher Slobogin is the Milton R. Underwood Chair in Law and Director of the Criminal Justice Program at Vanderbilt University.

${ }^{50}$ Faigman, Monahan, and Slobogin, "Group to Individual (G2i) Inference in Scientific Expert Testimony.”
} 
based in either poor experiences when dealing with the members of the scientific field or a fundamental difference in values or epistemology. The goal of this research is to determine if evidence exists for such a difference in confidence, causal determination if such a difference exists will require additional research.

\section{Methodology}

For this analysis a large-n quantitative observational design was utilized. The population for examination was extracted from the General Social Survey $1972-2014^{51}$ dataset and limited to include only those cases in which respondents answered the question "how much confidence do you have in the people running the scientific community?" The GSS data provided a total valid response population of 35,166 cases. Both ordinary least squares and binary logistic regression were performed to assess the hypothesis that legal professionals will have less confidence in the scientific community than their peers in other fields. The null hypothesis in this case states that legal professionals do not have less confidence in the scientific community than their peers in other fields.

\section{Variables and Measures}

\section{Dependent Variable}

Response to the question "how much confidence do you have in the people running the scientific community?" provided the best measure for a dependent variable which reflects confidence in the scientific community. For OLS regression analysis the variable (label:

CONSCI) was treated as an ordinal measure with values of 1 (Hardly any) 2 (Only some) or 3 (A

\footnotetext{
${ }^{51}$ The General Social Survey (GSS) is a project of the independent research organization NORC at the University of Chicago, with principal funding from the National Science Foundation.
} 
great deal). For the binary logistic regression a binary variable (label: CONSCILog) was constructed for responses of "A great deal" with all other valid responses valued at 0 .

\section{Independent Variables}

The primary independent variable for this study is whether or not a respondent is a legal professional. This variable (label: OCCStandard) was constructed as a binary from three variables (OCC, OCC80, and OCC10) used during different cycles of the GSS survey. Each variable was coded using nominal occupation identifiers based on U.S. Bureau of the Census occupation and industry codes. For the purpose of this research, the group of occupations which was coded 1 for legal professional included: Judges, Lawyers, Legal assistants, Miscellaneous legal support workers, Paralegals, Judicial law clerks, and Legislators. All other valid occupation responses were coded 0 .

To provide the best possible measure of any variation which may exist between professions, it was critical to control for other factors which are shown to influence attitudes towards science. Using prior statistical work done by the Pew Research Center ${ }^{52}$ the following possible confounding influences were identified: Political ideology, Age, Education, Sex, Race, and Religious attendance. Appropriate controls for all but Race were found within the GSS data and utilized in the following ways:

- Political ideology was measured using a GSS variable (POLVIEWS) which codes responses into a seven-point ordinal measure ranging from extremely liberal (1) to extremely conservative (7). Although the measure is not exact and the terms doubtless mean different things to each respondent, the variable provides sufficient discrimination

\footnotetext{
${ }^{52}$ Funk, Cary, and Lee Rainie. "Chapter 1: Patterns Underlying Public Views About Science." Pew Research Center: Internet, Science \& Tech, July 1, 2015. http://www.pewinternet.org/2015/07/01/chapter-1-patternsunderlying-public-views-about-science/.
} 
to justify its ordinal treatment. For the purposes of this research we would not gain significant insight by converting to seven binary variables. Each increase in this variable indicates an increase in self-identified conservativism.

- Age was measured using a GSS variable (AGE) which codes responses by discrete number of years since the respondent's birth. As such, this is an interval/scale variable with the exception that all persons aged 89 years or more are coded as 89 . It would certainly be possible to code this variable for age groups, but any grouping would be arbitrary in some way and decrease the representational value of the variable. To avoid needless complication of the data it was determined that the existing scale would serve the purposes of this research.

- Education was measured using a GSS variable (DEGREE) which codes responses based on categorical levels of educational achievement beginning with less than high school (1) and ranging to completion of a graduate degree (5). As with political ideology, this variable is treated as an ordinal measure of education. The categories include established socially contextualized measures of education that can be easily distinguished and interpreted.

- Sex was measured using a GSS variable (SEX) which has been modified to create a binary differentiation between men (0) and women (1). As with the legal professional variable (OCCStandard), this is nominal and allows for no interval discrimination nor meaningful ordinal treatment.

- Religious attendance was measured using a GSS variable (ATTEND) which has been modified to reduce the number of categories to a more manageable level. Responses are 
coded based on how respondents measure their attendance at religious gatherings. The variable provides ordinal categories ranging from less than once a year (1) to more than once a week (5). Although Pew identified some variance between religious denominations attitudes towards science ${ }^{53}$, the creation of a nominal binary variables for denominational discrimination did not improve modeling.

- Race was not available as a meaningful variable for analysis in this study. The GSS cases included 0 responses for black legal professionals. The only available differentiation would be white or other.

\section{Regression Results}

OLS Regression - Dependent Variable Confidence in Scientific Community

\begin{tabular}{|l|l|l|l|}
\hline Constant & 2.357 & .016 & $.000 * * *$ \\
\hline Variables: & $\mathrm{B}$ & Std. Error & Significance \\
\hline Legal Professional & .040 & .040 & .326 \\
Pol. Ideology & -.013 & .002 & $.000 * * *$ \\
Age & -.001 & .000 & $.000 * * *$ \\
Education & .092 & .003 & $.000 * * *$ \\
Sex (Female) & -.076 & .007 & $.000 * * *$ \\
Religious Attendance & -.026 & .003 & $.000 * * *$ \\
\hline R Square & .044 & $\mathrm{n}=35,166$ \\
* significant at $\mathrm{p}<.05 * *$ significant at $\mathrm{p}<.005 * * *$ significant at $\mathrm{p}<.001$
\end{tabular}

Binary Logistic Regression - Dependent Variable Confidence in Scientific Community (Binary)

\begin{tabular}{|l|l|l|l|l|}
\hline Constant & -.123 & .054 & $.022 * *$ & .885 \\
\hline Variables: & $\mathrm{B}$ & Std. Error & Significance & $\operatorname{Exp}(\mathrm{B})$ \\
\hline Legal Professional & .162 & .141 & .252 & 1.176 \\
Pol. Ideology & -.043 & .008 & $.000 * * *$ & .958 \\
Age & -.004 & .001 & $.000 * * *$ & .996 \\
Education & .266 & .010 & $.000 * * *$ & 1.304 \\
Sex (Female) & -.294 & .023 & $.000 * * *$ & .745 \\
Religious Attendance & -.102 & .009 & $.000 * * *$ & .903 \\
\hline
\end{tabular}




\begin{tabular}{|l|l|}
\hline C \& S R Square $\quad .037 \quad \mathrm{n}=35,166$ \\
$*$ significant at $\mathrm{p}<.05 * *$ significant at $\mathrm{p}<.005 * * *$ significant at $\mathrm{p}<.001$
\end{tabular}

\section{Discussion}

The findings published by Pew Research based on their analysis are confirmed by the analysis conducted for this project. The variables used to measure their predicted influencing factors provided statistically significant indications of such influence. Regressions confirm that political ideology, age, education, sex, and religious attendance all appear to be relevant to confidence in the scientific community. The relevance of whether a person is a legal professional is less clear. While the OLS regression's B value of .040 is substantial, meaning that legal professional's responses will tend to be .40 higher (more confidence in science community) on a scale of 1-3 than other similarly situated professionals, the standard error (.40) and p value (.329) indicate that the B value may be a result of sampling error. The binary logistic regression provides a B value of .162 and an Exp (B) of 1.176 which represent a $17.6 \%$ higher likelihood that legal professionals will rate their confidence in the scientific community at the highest level than other similarly situated professionals. Like the OLS regression though, these results are tempered by the std. error (.141) and p value (.252). Additionally, it is important to note that both regressions indicate that the initial hypothesis is incorrect, that confidence may be higher for legal professionals than their peers.

Several possibilities are suggested as a result of these regressions. First, the respondents may be too heterogeneous. Considering that this data is not only national in scope, but also covers a period of more than 30 years, the attitudes may be strongly influenced too many factors to make a meaningful assessment. Second, the sample of legal professionals may simply be too small to provide a meaningful representation of legal professionals overall. While the proportion 
to all respondents may be reasonable, the universe of responses from legal professionals does not create the necessary space to demonstrate the nuance within the field. Third, factors affecting attitude towards science may be substantially more complex than is currently possible to measure.

The third possibility is important to consider particularly in light of the $\mathrm{R}$ squared values of these regressions. The small $\mathrm{R}$ squared values indicate that even if all variables are taken as significant, they are cumulatively only accounting for a very small portion of a respondent's confidence in the scientific community. The model requires substantial improvement. Some other variables may be able to provide such improvement including: race, region or locality type (low or high population density for instance), field of undergraduate study, and religious denomination. As was mentioned in the methodology section, race was not able to be effectively integrated into these regressions because of the complete absence of black representation among legal professionals. Based on the prior Pew Research work, ${ }^{54}$ there is reason to expect that even the single variable addition of race could significantly improve the value of the model.

Finally, it is worth noting the possibility of a flaw in the research design. When searching for a reasonable dependent variable to best address the question of attitudes toward science it became apparent that there were several variables which might serve that purpose for measurement. Unfortunately, only the CONSCI variable has been used consistently during the administration of the GSS. This variable, therefore, provided the highest $\mathrm{n}$ value available. It is possible however that an answer to the question "how much confidence do you have in the people running the scientific community?" does not demonstrate a representation of confidence in the scientific community overall, nor of an overall attitude towards science.

\section{Conclusions}

${ }^{54}$ Ibid. 
Although the data available from the GSS is vast and valuable, it does not offer sufficient specificity for the purposes of this research question. While we are able to glimpse a suggestion of a relationship, the value of that glimpse is lessened by the heterogeneity of the sample. This project has demonstrated the need for a more focused analysis, starting with the legal community, if such policy-relevant attitudes are to be examined.

While it was initially believed that this question was best framed to encompass all legal professionals, it will likely be more productive to start with legal professionals specializing in areas which deal regularly with expert testimony. A study which conducted a comprehensive survey of members of the legal community could provide the data necessary. Such survey data would provide for the possibility of precise discrimination. Research would be able to substantiate causal theories based on the nuance of any variances that may exist. In the instance that a similar variance was observed between all legal professionals as compared to other professions, it would provide evidence for the fundamental difference in values and practices proposed by Haack. Alternatively, a measurable variance within the legal profession between people involved with expert testimony and those who are not would substantiate the possibility that experience from practice dealing with scientific experts is a causal factor.

As for effective conclusions which can be drawn from this research, the following can be determined:

1. There is a suggestion that legal professionals may actually be more confident in the scientific community than their peers in other fields.

2. The high standard error and poor significance value make this suggestion tenuous at best.

3. It is possible that the suggestion results from an incomplete model, which is supported by the low R squared values. 
4. Data is presently not sufficient to substantiate a causal factor determination, such as experience or fundamental differences between professions in law and science.

Any additional determination concerning a relationship between a person's status as a legal professional and their confidence in science will require a data source better suited to the research question. 


\section{Bibliography}

Brent, R. "Medical, Social , and Legal Implications of Treating Nausea and Vomiting of Pregnancy." American Journal of Obstetrics \& Gynecology 186, no. 5 (May 18, 2002): $262-66$.

Cheng, Edward K., and Albert H. Yoon. "Does Frye or Daubert Matter? A Study of Scientific Admissibility Standards." Virginia Law Review 91, no. 2 (2005): 471-513.

Chesebro, Kenneth J. “Galileo's Retort: Peter Huber's Junk Scholarship.” American University Law Review 42, no. 4 (1993): 1637-1726.

Coppola, Francis Ford. The Rainmaker. Crime, Drama, Thriller, 1997.

Faigman, David L., John Monahan, and Christopher Slobogin. "Group to Individual (G2i) Inference in Scientific Expert Testimony." University of Chicago Law Review 81, no. 2 (Spring 2014): 417-80.

Foster, Kenneth R., David E. Bernstein, and Peter W. Huber. Phantom Risk: Scientific Inference and the Law. MIT Press, 1999.

Foster, Kenneth R., and Peter W. Huber. Judging Science: Scientific Knowledge and the Federal Courts. MIT Press, 1999.

Freedman, Alix M., and Laurie P. Cohen. "Smoke and Mirrors: How Cigarette Makers Keep Health Question `Open' Year After Year --- Council for Tobacco Research Is Billed as Independent But Guided by Lawyers --- An Industry Insurance Policy." Wall Street Journal, Eastern Edition. February 11, 1993.

Funk, Cary, and Lee Rainie. "Chapter 1: Patterns Underlying Public Views About Science." Pew Research Center: Internet, Science \& Tech, July 1, 2015. http://www.pewinternet.org/2015/07/01/chapter-1-patterns-underlying-public-viewsabout-science/.

Galanter, Marc. "Why the 'Haves' Come Out Ahead: Speculations on the Limits of Legal Change." Law and Society Review 9 (1974): 95-169.

Haack, Susan. "Irreconcilable Differences? The Troubled Marriage of Science and Law." Law \& Contemporary Problems 72, no. 1 (Winter 2009): 1-23.

— . "Trial and Error: The Supreme Court's Philosophy of Science." American Journal of Public Health 95, no. S1 (July 1, 2005): S66-73. doi:10.2105/AJPH.2004.044529.

_. "Truth and Justice, Inquiry and Advocacy, Science and Law." Ratio Juris 17, no. 1 (March 1, 2004): 15-26. doi:10.1111/j.0952-1917.2004.00252.x. 
Huber, Peter W. Galileo's Revenge: Junk Science in the Courtroom. Basic Books, 1993.

—. Liability: The Legal Revolution and Its Consequences. New York: Basic Books, 1990.

Huber, Peter W., and Robert E. Litan, eds. The Liability Maze: The Impact of Liability Law on Safety and Innovation. Washington, D.C: Brookings Institution Press, 1991.

Krafka, Carol, Meghan A. Dunn, Molly Treadway Johnson, Joe S. Cecil, and Dean Miletich. "Judge and Attorney Experiences, Practices, and Concerns Regarding Expert Testimony in Federal Civil Trials." Psychology, Public Policy, and Law 8, no. 3 (September 2002): 309-32. doi:http://dx.doi.org.proxy.lib.pdx.edu/10.1037/1076-8971.8.3.309.

Sanders, Joseph. "Science, Law and the Expert Witness." Law and Contemporary Problems 72, no. 1 (January 1, 2009): 63-90.

Smith, Abbe, and Monroe H Freedman. Understanding Lawyers' Ethics. 4th ed. New Providence, NJ: LexisNexis, 2010.

Southworth, Ann, Anthony Paik, and John P. Heinz. "Lawyers in National Policymaking." SSRN Scholarly Paper. Rochester, NY: Social Science Research Network, May 10, 2010. http://papers.ssrn.com/abstract=1604080. 


\title{
Appendix A
}

\author{
Annotated Bibliography
}

Haack, Susan. "Irreconcilable Differences? The Troubled Marriage of Science and Law." SSRN Scholarly Paper. Rochester, NY: Social Science Research Network, August 27, 2009. http://papers.ssrn.com.proxy.lib.pdx.edu/abstract=1462930.

Haack believes that the law often calls on those fields of science where the pressure of commercial interests is most intense. She argues that the incompatibility of the law and science may be a result of case-specificity which requires answers that science may not be prepared to clearly answer. The law tends to draw in scientists who are more willing to give an opinion based on less evidence. As the frequency of testifying increases a witness can become undeservedly confident in his opinion. Legal rules can make it impossible to even examine useful scientific information and may completely misinterpret scientific subtleties. She believes its concern for precedent, and the desire for finality, causes the law to lag behind scientific advances. Haack serves as central to the examination of a fundamental difference which may influence the attitudes of legal professionals.

Sanders, Joseph. "SCIENCE, LAW, AND THE EXPERT WITNESS." Law and Contemporary Problems 72, no. 1 (January 1, 2009): 63-90.

The analysis by Sanders contends that specific conventions of law and conventions of science create incompatibility when these two areas interface. He believes that within American law the adversarial system, and the need for closure in each case, create direct conflicts to the scientific conventions of: commitment to data sharing, intellectual honesty, disinterestedness, and agnosticism while awaiting persuasive evidence. These incompatibilities place tremendous social and professional strain on expert witnesses. Sanders proposes a remedy which includes specific training and acknowledgement for expert witnesses before their testimony. Sander's argument supports Haack's and provides evidence of a fundamental difference in values which may influence attorney's attitudes.

Smith, Abbe, and Monroe H Freedman. Understanding Lawyers' Ethics. New Providence, NJ: New Providence, NJ : LexisNexis, 2010. Freedman and Smith outline a view of lawyers' ethics that places the client squarely in the center of moral and ethical considerations of duty. They contextualize lawyers' decision making process as related to view of duty and ethical responsibility to clients. The authors acknowledge that in many cases it may be necessary to effectively discredit or completely misrepresent testimony or evidence which is known to be truthful. As a highly regarded text on the ethics of legal practice, this book serves as a good instrument for examination of comparative values.

Galnter, Marc. "Why the 'Haves' Come Out Ahead: Speculations on the Limits of Legal Change." Law and Society Review 9 (1974): 95-169.

Galanter formulates a typology of participants within American law. His typology, based in research and observation, explains outcomes of actions attempting to secure legal change. His RP and OS groups are extremely useful for consideration of the uses of science and 
expert testimony. He argues that RP participants possess the ability to fight for legal rule change, while OS participants typically do not.

Huber, Peter W. Galileo's Revenge: Junk Science in the Courtroom. Basic Books, 1993.

Huber constructs an indictment of the growing role of, what he sees as, junk science in U.S. courtrooms. He presents examples which suggest that lawyers are victimizing companies and organizations through the arm of "liability science" empowered by spurious claims and fraudulent or charlatan expert witness testimony. His argument holds doctrinal decisions responsible for creating the environment of abuse. He proposes the possible solution being straight forward and discreet reform of the tort system within the U.S. This position runs counter to Haack's and Sander's view of a fundamental difference as the driving factor behind the poor performance of science in the courtroom. 